\title{
Haid daripada Perspektif Sains dan Maqasid Syariah
}

(Menses from the Perspective of Science and Maqasid Syariah)

\author{
Nur ASMADAYANA Hasim, MOHD IZHAR ARIFF MOHD KASHIM, RIZAFIZAH OTHAMAn, MOHAMMAD ZAINI YAHAYA, \\ ROZIDA KHALID \& MUHAMMAD ADIB SAMSUDIN*
}

\begin{abstract}
ABSTRAK
Setiap kejadian semula jadi merupakan rahmat dan memberi kemaslahatan kepada manusia termasuklah pendarahan haid dalam kalangan wanita. Haid merupakan suatu proses yang unik dan terancang yang melibatkan tiga fasa utama iaitu fasa haid, fasa folikel dan fasa luteal. Objektif penyelidikan ini ialah untuk mengkaji dan menghubungkaitkan kebaikan haid daripada perspektif sains dan maqasid syariah. Kajian ini dijalankan dengan menggunakan ulasan literatur secara deskriptif. Kajian mendapati bahawa perubahan hormon, warna darah dan faktor fiziokimia lain memberi kesan terhadap kenormalan kitaran haid. Darah haid juga dikenal pasti mempunyai agen antimikrob terutamanya terhadap bakteria E. coli dan bakteria Gram-negatif lain. Hal ini bertepatan dengan maqasid syariah memelihara jiwa kerana haid mampu juga memelihara kesihatan wanita. Selain itu, kajian lepas menemukan bahawa darah haid terdiri daripada sel stem yang boleh digunakan dalam aktiviti klinikal pada masa akan datang. Maqasid syariah melindungi keturunan juga dapat dilihat dengan kehadiran haid yang sering digunakan bagi menjangkakan waktu subur bagi merancang kehamilan. Hikmah Islam melarang mendekatkan diri (bersetubuh) dengan wanita yang sedang haid adalah satu rahmat yang besar, kerana wanita yang sedang haid biasanya mempunyai kelaziman gejala prahaid (PMS) yang melibatkan isu kesihatan. Oleh itu, haid daripada perspektif sains adalah bertepatan dengan maqasid syariah.
\end{abstract}

Kata kunci: Antimikrob; haid; kelaziman gejala prahaid (PMS); maqasid syariah; sel stem

\section{ABSTRACT}

Each natural occurrence is a blessing and gives benefit to human being such as menstruation in women. Menstruation is a unique and planned process, which involves three main phases; the menstrual phase, the follicular phase and the luteal phase. The objectives of this research were to study and relate the benefits of menses from the perspective of science and maqasid syariah. The research was conducted using descriptive literature review. It was found that hormonal changes, colour of menstrual blood and other physiochemical factors affect the normality of the menstrual cycle. Menstrual blood has been recognized as an antimicrobial agent against bacteria, especially E. coli and other Gram-negative bacteria. This coincided with the maqasid syariah of preserving soul since menstruation can also preserve women's health. In addition, previous study reported that menstrual blood has stem cells that can be used for clinical activities in the future. Menstruation can also be considered as maqasid syariah of protecting the next generation due to consistency of the 'fertile time'for pregnancy planning purpose. Islam prohibits the sexual intercourse with women who are in menstruation because women at this state normally have a prevalence of premenstrual symptoms (PMS) that involves health issues. Thus, menstruation from science point of view is in agreement with maqasid syariah.

Keywords: Antimicrobial; maqasid syariah; menstruation; prevalence of premenstrual symptoms (PMS); stem cells

\section{PENDAhUluan}

Islam diturunkan untuk menjaga kemaslahatan manusia. Firman Allah SWT yang bermaksud: Dan tiadalah Kami mengutus kamu melainkan untuk (menjadi) rahmat bagi semesta alam (Al-Anbiyaa' 21:107). Ini menunjukkan bahawa agama Islam yang diturunkan melalui Nabi Muhammad SAW bertujuan untuk membawa rahmat kepada seluruh manusia (Muhammad Adib et. al 2015). Kerahmatan ini dapat dilihat melalui kejadian semula jadi yang dicipta oleh Allah SWT. Misalnya keseluruhan anggota tubuh badan manusia dicipta dengan fungsi masing-masing bertujuan untuk memberi kebahagiaan dan kesejahteraan kepada manusia itu sendiri. Mata dicipta untuk melihat.
Begitu juga fungsi telinga ialah untuk mendengar. Keduadua anggota badan yang dipilih sebagai contoh ini adalah manifestasi kepada sifat rahmat Allah SWT. Selain itu, kejadian semula jadi yang juga mendatangkan rahmat juga membawa kemaslahatan kepada manusia ialah pendarahan haid. Dengan kata lain, pendarahan haid kepada insan bergelar wanita adalah dengan kehendak Allah swT dalam menjaga kemaslahatan mereka atau nama lainnya maqasid syariah.

Haid jika dilihat daripada karya-karya fiqh bermaksud darah yang keluar dari pangkal rahim dalam tempoh yang tertentu secara tabii melalui faraj wanita dalam keadaan sihat, bukan sebab melahirkan anak (al-Sharbini 1994). 
Takrifan ini tidak jauh berbeza dengan takrifan haid daripada aspek perubatan. Medical dictionary (2013) mendefinisikan haid sebagai penumpahan endometrium secara berkala yang keluar daripada rahim wanita dan menurut Ferenczy (2003) darah itu keluar daripada bahagian atas mukosa endometrial.

Kitaran haid boleh dibahagikan kepada tiga fasa utama: fasa haid, fasa folikel dan fasa luteal (Rajah 1). Ia menjadi kebiasaan untuk menetapkan hari pertama kitaran sebagai hari pertama fasa haid yang juga dikenali sebagai pendarahan haid. Ia merujuk pada hari haid bermula dan ia dipilih sebagai titik permulaan haid. Fasa haid boleh bertahan dari 1 ke 7 hari, tetapi biasanya berlangsung selama 4 atau 5 hari (Richard \& Kristin 2014). Ini adalah sama dengan pandangan dalam mazhab Syafie (al-Sharbini 1994) berdasarkan hadis yang mengatakan kitaran haid biasanya antara 6-7 hari. Nabi Muhammad SAw bersabda yang diriwayatkan oleh Abu Daud pada kitab al-haid bab hukm al-mustahadah: 'Jalanilah pendarahan haid menurut hukum yang dikehendaki oleh Allah swT selama 6 atau 7 hari'. Hadis ini menjadi bukti bahawa Rasulullah SAW menjadikan adat kebiasaan sebagai rujukan dalam pengiraan tempoh haid (Ibn al-Najjar 1993), namun baginda tidak menyatakan kaedah yang digunakan untuk mengetahui kebiasaan tersebut. Hadis ini menjadi asas kepada penetapan kebiasaan darah yang keluar dalam tempoh kitaran haid ialah selama 6-7 hari (al-Sharbini 1994). Haid yang biasanya dibincangkan di dalam Islam merujuk kepada fasa haid sahaja. Namun dalam sains, kitaran haid merangkumi ketiga-tiga fasa.

Menurut Richard dan Kristin (2014), fasa kedua iaitu fasa folikel bermula pada akhir haid, contohnya hari ke-6 jika haid berlaku selama 5 hari. Semasa fasa folikel, ovari meneruskan pembentukan folikel-folikel yang bermula semasa fasa haid dan merembeskan estradiol, yang seterusnya menyebabkan penebalan lapisan endometrium rahim. Fasa ini berterusan sehingga ovulasi (folikel dominan akan membebaskan ovum) yang biasanya berlaku pada kira-kira hari ke-14 untuk kitaran 28 hari dan pada hari ke-16 untuk kitaran 30 hari. Dengan itu, ovulasi biasanya berlaku kira-kira 14 hari sebelum bermulanya haid yang seterusnya. Sekiranya darah masih mengalir pada fasa ini ia masih dianggap pendarahan haid menurut Islam (al-Sharbini 1994).

Fasa terakhir dalam kitaran haid iaitu fasa luteal yang bermula selepas ovulasi hingga ke hari pertama haid. Pada fasa ini, folikel dominan yang kosong membentuk korpus luteum dengan sokongan hormon pituitari. Korpus luteum akan menghasilkan progesteron yang meningkatkan penghasilan estrogen untuk 2 minggu berikutnya. Progesteron memainkan peranan penting dalam menukar endometrium proliferatif menjadi lapisan penerima rembesen bagi pembenihan dan sokongan bagi awal hamil. Jika persenyawaan tidak berlaku, ovum dicuci keluar daripada badan dalam aliran haid. Jika persenyawaan berlaku, embrio akan terbenam pada lapisan endometrium dalam rahim dan menghalang wanita untuk haid (Richard \& Kristin 2014).
Menurut Islam, darah yang keluar pada fasa terakhir ini dinamakan darah istihadah. Darah istihadah ialah darah yang keluar berterusan daripada fasa haid dan folikel atau pun darah yang keluar dalam fasa luteum ini walaupun sudah berhenti pada fasa sebelumnya (al-Sharbini 1994) Oleh itu, pengiraan hari bermula pada hari pertama haid adalah sangat penting sebagai penunjuk sama ada darah tersebut adalah darah haid ataupun darah istihadah. Dalam Islam, darah istihadah dikira darah penyakit dan wanita Islam perlu melakukan ibadah seperti biasa sebagai contoh solat, puasa dan tawaf (al-Nawawi t.th; al-Nawawi 1992; al-Sharbini 1994).

Masalah yang sering dihadapi wanita ialah menentukan kitaran darah haid dan sering menjadi perbincangan dalam kalangan umat Islam. Namun, corak yang tidak teratur pada haid adalah sesuatu yang biasa daripada sudut sains bagi wanita normal disebabkan perubahan hormon yang berlaku dan menjadi sebab beberapa gangguan pada kematangan folikel (Richard \& Kristen 2014). Barry dan Stanley (1974), telah menjalankan kajian perubahan dalam paras serum hormon luteal, hormon perangsang folikel, estradiol dan progesteron pada wanita muda, wanita normal dan wanita yang mempunyai masalah haid. Wanita muda biasanya mempunyai satu fasa folikel yang panjang dan tempoh antara haid yang tidak berkala. Wanita normal mempunyai kitaran haid yang normal seperti yang dibincangkan dalam Rajah 1. Manakala, wanita yang mempunyai masalah haid ialah wanita pra-menopaus yang juga berkait dengan peningkatan usia dan penggunaan IUD, individu yang mempunyai kitaran haid yang panjang, aliran haid panjang atau aliran haid yang berat (Nancy et al. 1982) kitaran haid yang pendek atau panjang.

Islam turut menggariskan darah haid berdasarkan warna. Antara warna yang terdapat dalam kitab-kitab fekah ialah merah kehitaman, merah, merah keemasan, merah kekuningan dan keruh (warna tanah) (al-Sharbini 1994). Justifikasi warna darah yang dibincangkan ini banyak dikaji daripada sudut sains. Aliran haid yang sihat dipercayai berwarna merah terang disebabkan oleh peratusan hemoglobin. Haid yang berwarna merah gelap atau/merah wain biasanya dikaitkan dengan peningkatan keradangan dan penghasilan prostaglandin. Haid yang berwarna gelap menunjukkan peningkatan pengoksidaan hemoglobin yang melambatkan aliran haid. Malah darah haid yang gelap juga berkemungkinan disebabkan oleh endometriosis (terutamanya berwarna sangat coklat gelap atau sangat merah gelap). Darah haid yang gelap bersifat pekat dan berwarna coklat. Manakala darah haid yang pucat dan cair menunjukkan peralihan perimenopausal yang disebabkan oleh kebiasaan perempuan yang berpengalaman dalam pengeluaran darah haid. Selain itu, warna darah haid juga merujuk kepada keseimbangan hormon yang kurang terkawal (Hechtman 2014). Darah haid beku yang kecil dianggap satu komponen biasa dalam pendarahan haid. Mereka biasanya menunjukkan aliran darah yang terbentuk dan berlebihan. Saiz darah beku bergantung kepada kekurangan zat besi dan kehadiran tisu endometrium (Hechtman 2014). 


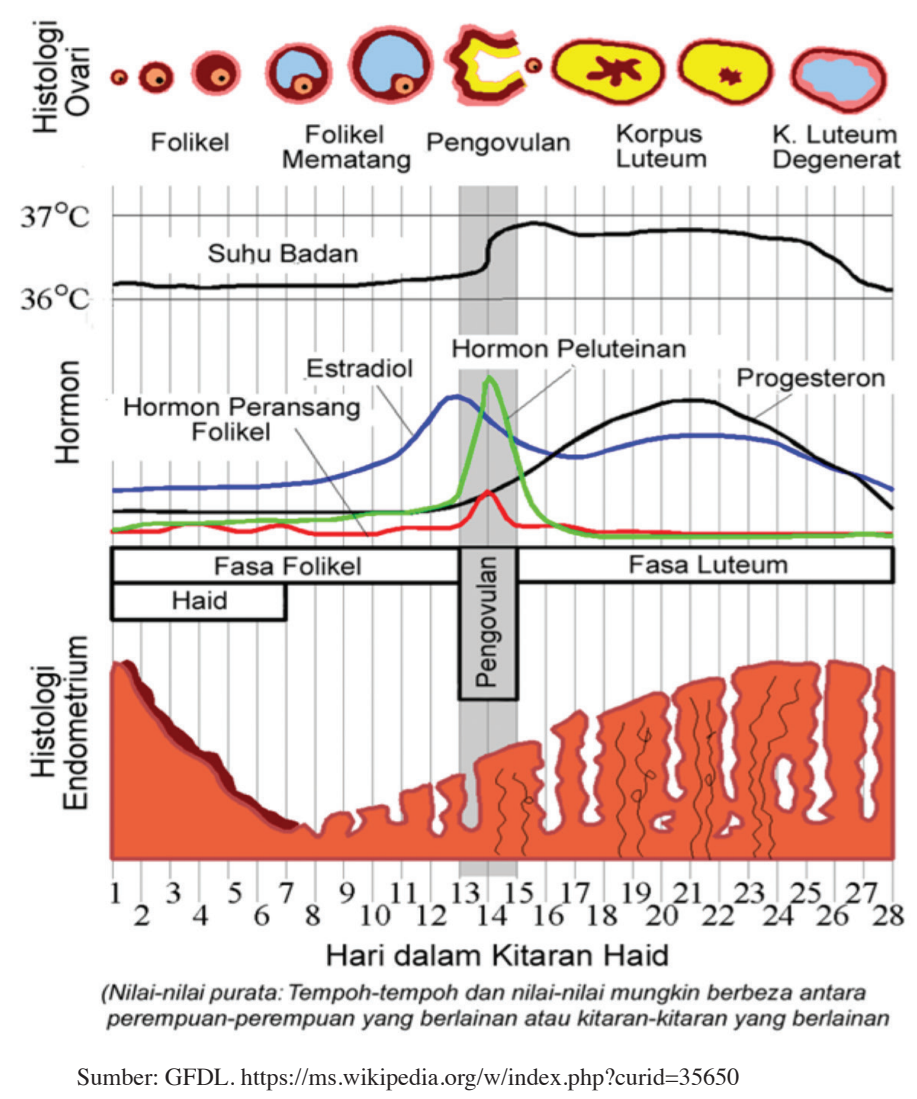

RAJAH 1. Hari dalam kitaran haid

\section{DARAH HAID BERSIFAT ANTI BAKTERIA}

Kedatangan haid ini adalah kemaslahatan yang telah terbukti melalui kajian saintifik. Kemaslahatan yang dimaksudkan ialah darah haid manusia mengandungi sebatian anti bakteria. Darah haid yang normal daripada wanita sihat sangat kaya dengan pecahan hemosidinhaemoglobin yang mempunyai ciri bakterisidal (Mak et al. 2000). Hemoglobin (Hb) merupakan sumber peptida bioaktif yang bersifat analgesik, hemopoietik, penggalak pengecutan koranoarteri dan antigonadotropik (Karelin et al. 1998; Petrov et al. 1997). Preethi dan Jayanthi (2012) juga telah membuktikan bahawa $\mathrm{Hb}$ dipecahkan untuk menghasilkan banyak sebatian aktif secara biologi seperti hemosidin yang berperanan menggalakkan ciri antimikrob. Mekanisme aktiviti bakterisidal hemosidin berkait dengan struktur alfa helikal amfifatik yang terbentuk semasa bersentuhan dengan fosfolipid membran bakteria yang bercas negatif yang menyebabkan kemusnahan terhadap integriti membran dan kematian sel (Mak et al. 2001).

Terdapat juga kajian mengenai hemosidin dalam pemencilan peptida daripada homogen plasenta manusia atau pemecahan sel-sel darah merah (Liepke et al. 2003) ketika pendarahan haid. Salah satu peptida ini dikenali sebagai pecahan janin gamma-Hb, manakala peptida yang lain daripada beta-Hb. Kedua-dua peptida ini membunuh bakteria Gram-negatif dan bakteria Gram-positif pada kepekatan 10 mikromol/L, namun khususnya bertindak secara langsung dengan $E$. coli, iaitu sejenis patogen urogenital. Namun, peptida ini tidak efektif dalam melawan patogen kulat yang oportunistik iaitu Candida albicans. Secara keseluruhannya, hemosidin penting bagi memelihara homoestasis mikrob vagina semasa berlakunya haid (Mak et al. 2000). Kajian lain pula membuktikan bahawa 9-10 fragmen peptida daripada darah haid mempunyai aktiviti antibakteria terhadap E. coli sehingga $100 \%$. Mekanisme antimikrob fragmen peptida ini seakanakan meniru mekanisme tindakan antimikrob alfa helikal peptida klasik, seperti melitin, cecropins, pardaxin atau LL-37 (Shai 1999).

Aktiviti bakteria daripada dua kes diuji pada hemosidin daripada pelepasan haid (alpha-globin, sisa 3556, dan betaglobin, sisa 115-146, (Jadual 1) adalah sama dengan yang ditentukan dalam penyelidikan lain (Liepke et al. 2003; Parish et al. 2001), kedua-dua dalam kes nilai MIC (dari puluhan ke ratusan $\mu \mathrm{M}$ ) serta keberkesanannya terhadap bakteria Gram-negatif. Satu-satunya perbezaan adalah kekurangan aktiviti ke arah $C$.albicans. Hemosidin dalam haid juga menunjukkan kesan tindakan sinergi terhadap E. coli. Malah, terdapat kemungkinan ciri untuk peptida mikrobisidal yang lain wujud (Levy et al. 1994; Saunders \& Cohen 1995) dan memberi kesan kepada hemosidin dalam faraj untuk menggalakkan peranannya kerana anggaran kandungan jumlah hemosidin dalam haid adalah dalam pelbagai puluhan $\mu \mathrm{M}$. Salah satu ciri yang paling penting daripada hemosidin dalam haid adalah aktiviti mereka yang tinggi terhadap E. coli terdiri 
daripada peptida ini kerana saluran kencing dipenuhi dengan mikroorganisma ini yang merupakan satu masalah kesihatan bagi wanita (Manges et al. 2001).

Sistem pertahanan imun bagi sistem reproduktif wanita adalah rumit dan dinamik yang juga melibatkan sekatan fizikal yang khusus atau fiziokimia (epitalia, lendir, $\mathrm{pH}$ yang rendah dan hidrogen peroksida), mikroflora komensal (terutamanya Lactobacillus sp., Gardnerella vagnalis dan Staphylococcus epidermidis), antibodi, sel efektor dan juga protein dan peptida bakteria. Faktor lain yang menjadi sekatan perlindungan sistem reproduktif wanita daripada pelbagai bawaan patogen secara seksual adalah sebatian antimikrob semula jadi yang dihasilkan daripada endometrium seperti lisozim, laktoferrin, perencat perembesan proteinase, elafin, kathelisidin dan defensin (King et al. 2003; Quayle 2002; Russell \& Mestecky 2002).

\section{DARAH HAID MENGANDUNGI SEL STEM}

Menurut Zainal Ariffin et al. (2005), sel stem mampu untuk melalui proses pembahagian dan pembezaan sel kerana sel stem merupakan sel induk. Malah, satu sel daripada sel stem yang primitif mampu menghasilkan satu organisma yang lengkap. Pecahan stromal stem sel daripada pelbagai jenis tisu dan organ menggalakkan ciri stem sel yang berupaya untuk memperbaharui sendiri dan bermultipotensi sekali gus membenarkan perbezaan pelbagai keturunan. Sel stem embrionik (ESCS) mempunyai keupayaan totipoten iaitu keupayaan untuk membeza menjadi apa-apa jenis sel yang diperoleh daripada semua tiga lapisan germa (Ludwig et al. 2006; Thomson et al. 1998). Namun, kadar permintaan sel stem untuk rawatan pelbagai penyakit seperti kegagalan jantung (Patel et al. 2005), kecederaan saraf tunjang (Nandoe et al.2006), tulang dan pembaikan rawan (Vilquin \& Rosset 2006), adalah jauh tinggi berbanding dengan sumber yang ada, jadi sumber tambahan stem sel masih giat dikaji. Pecahan sel stromal daripada pelbagai tisu dan organ-organ telah ditunjukkan dalam multipotensi secara in vitro melalui pembezaan ke neurogenik, kardiogenik, osteogenik, adipogenik dan jenis sel kondrogenik (Chan et al. 2004; De Coppi et al. 2007; Toma et al. 2002; Zurita \& Vaquero 2004). Oleh itu, menjadi persoalan sama ada sumber multipoten stromal sel stem boleh didapati dengan selamat, boleh diperbaharui dan mengekalkan potensi untuk membeza jika digunakan.

Terbaharu, sel stromal telah dikenal pasti dalam tisu endometrial (Cho et al. 2004). Walau bagaimanapun, mendapatkan sel-sel secara langsung akan menjadi prosedur yang sangat sukar. Cara alternatif adalah daripada darah haid yang mengandungi darah dan tisu yang luruh daripada endometrium yang mengandungi satu populasi sel yang heterogenus yang berupaya untuk tumbuh semula (Cui et al. 2007). Sel rahim stromal mempunyai penanda multipoten sama yang biasa dijumpai di dalam sum-sum tulang (Kearns \& Lala; Schwab \& Gargett 2007; Taylor 2004).

Sel stem stromal telah terbukti mempunyai potensi yang besar untuk kegunaan masa hadapan dalam terjemahan klinikal terapi regeneratif (Toma et al. 2002; Vilquin \& Rosset 2006; Zurita \& Vaquero 2004). Darah haid manusia mempunyai ciri pada peringkat selular dan molekul, bersama-sama dengan keupayaan untuk dengan mudah berkembang dan dibezakan. Ia dikatakan mempunyai ciri yang sama seperti sel stem endometrium manusia (Cho et al. 2004). Oleh kerana mudah untuk dijadikan koleksi dan pengasingan, darah haid akan menjadi sumber potensi sel multipoten jika mereka juga dipamerkan sifat seperti sel stem yang lain (Patel et al. 2008).

\section{KESUBURAN}

Islam turut mengambil berat mengenai menjaga nasab. Dengan kata lain maqasid syariah ialah memelihara

JADUAL 1. Aktiviti mikrobial fragmen haemoglobin sintetik berdasarkan peptida yang terdapat dalam darah haid

\begin{tabular}{lcc}
\hline \multirow{2}{*}{ Mikroorganisma } & \multicolumn{2}{c}{ MIC $(\mu \mathrm{M})$} \\
\cline { 2 - 3 } & HbA 35-56 & HbB $115-146^{\mathrm{a}}$ \\
\hline Escherichia coli & 105 & 27 \\
Klebsiella Pneumoniae & 146 & 37 \\
Salmonella & 164 & 32 \\
Staphylococcus aureus & 222 & 61 \\
Enterecoccus faecalis & 293 & 40 \\
Micrococcus luteus & 281 & 48 \\
Candida albicans & $>300$ & $>300$ \\
\hline Escherichia coli & $26^{\mathrm{b}}$ & $6.7^{\mathrm{b}}$ \\
Enterecoccus faecalis & $147^{\mathrm{b}}$ & $20^{\mathrm{b}}$ \\
\hline
\end{tabular}

a $\mathrm{HbA}$ dan $\mathrm{HbB}$ menandakan rantaian alpha dan beta haemoglobin

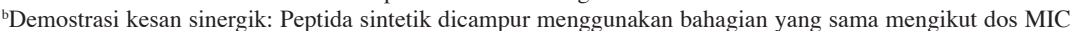
masing-masing dan dalam pencairan bersiri untuk mengetahui dos baru yang efektif terhadap bakteria Sumber: Mak et al. 2000 
keturunan (Al-Shatibiyy t.th). Nabi Muhammad SAW bersabda yang maksudnya: Berkahwinlah dengan wanita yang mencintaimu dan beranak pinak dengan banyak. Sesungguhnya aku berbangga dengan bilangan kamu berbanding dengan umat terdahulu (Abu Daud, kitab alnikah, bab al-nahy 'an tazwij man lam yalid min al-nisa', 2050). Hadis ini menunjukkan bahawa salah satu objektif perkahwinan atau maqasid syariah daripada hubungan seksual antara suami dan isteri ialah melahirkan zuriat. Maqasid ini juga terserlah melalui kitaran haid. Ini kerana nasab seseorang akan berkembang melalui kelahiran yang terlebih dahulu perlu melalui proses persenyawaan antara sperma dan ovum yang subur pada fasa luteal.

Maklumat harian untuk setiap kitaran haid diambil bagi menjangkakan hari-khusus yang berkemungkinan untuk hamil pada hari khusus yang berkait dengan ovulasi (David \& Donna 2002). Bagi kitaran haid wanita, terdapat enam hari yang persetubuhan boleh menyebabkan kehamilan; jendela kesuburan ini terdiri daripada lima hari sebelum ovulasi dan pada hari ovulasi itu sendiri (Dunson et al. 1999; Wilcox et al. 1995). Disebabkan hari ovulasi adalah berbeza daripada satu kitaran ke satu kitaran maka begitu juga waktu enam hari yang dikatakan subur. Namun, persetubuhan semasa jendela kesuburan semata adalah tidak mencukupi untuk hamil. Kehamilan juga bergantung kepada kebolehhidupan sperma dan telur, keterbukaan uterus dan pelbagai faktor lain yang berlaku dalam kalangan pasangan (Baird et al. 1999; Dunson et al. 1999). Tambahan pula, antara enam hari yang subur setiap kitaran, kebarangkalian untuk hamil (konsepsi) yang paling rendah ialah pada hari pertama (Wilcox et al. 1998).

Berdasarkan garis panduan klinikal terkini mengenai potensi hari kesuburan wanita, terdapat dua anggapan iaitu ovulasi berlaku 14 hari sebelum haid yang akan datang dan wanita akan subur untuk sesetengah hari sebelum dan selepas ovulasi. Jika mengikut kitaran haid biasa yang berpanjangan selama 28 hari, kesuburan dijangka antara hari ke-10 dan 17 (Beckman et al. 1998). Namun ada pendapat menyatakan bahawa jendela kesuburan berlaku lebih awal atau kemudian dalam kitaran. Secara purata, paling kurang $10 \%$ wanita yang mempunyai kitaran yang biasa mempunyai jendela kesuburan pada kitaran antara hari ke-6 dan ke-21. Jangkaan jendela kesuburan bagi wanita yang mempunyai kitaran yang tidak teratur adalah tidak tepat, termasuk bagi remaja dan wanita yang hampir putus haid (menopaus) (Egbert \& Peter 2002; Treloar et al. 1967).

Kitaran haid merupakan sesuatu yang penting bagi membuat perancangan keluarga bagi pasangan di seluruh dunia (Lamprecht \& Grummer-Strawn 1996). Terdapat beberapa hari dalam kitaran haid yang tidak berpontensi untuk hamil, termasuklah pada hari dalam kitaran yang mereka jangkakan permulaan haid yang akan datang. Perbincangan ini menunjukkan bahawa matlamat syarak atau maqasid syariah memelihara jiwa dengan pendarahan haid jelas kelihatan. Sekiranya tiada darah haid atau kedatangan haid tidak teratur nescaya wanita tidak menikmati kebaikan sepenuhnya seperti yang dirasai oleh wanita yang melalui pendarahan haid secara normal.
Kemaslahatan ini ditambah lagi dengan keizinan yang diberikan oleh Islam kepada wanita yang mengalami pendarahan haid untuk meninggalkan kewajipan mengerjakan sembahyang lima waktu. Pada masa yang sama, Islam menetapkan bahawa persetubuhan antara suami dan isteri juga tidak dibenarkan semasa pendarahan haid berlaku. Firman Allah SwT yang bermaksud (alBaqarah 2:222) 'Mereka bertanya kepadamu tentang haid. Katakanlah haid itu memudaratkan. Oleh sebab itu hendaklah kamu menjauhkan diri (tidak bersetubuh) daripada wanita pada waktu haid; dan janganlah kamu mendekati mereka sebelum mereka suci... (Ibn 'Ashur 1984:2/364). Ini jelas menunjukkan bahawa persetubuhan dilarang ketika isteri dalam keadaan haid. Sebabnya dinyatakan dalam ayat yang sama iaitu memudaratkan.

Hal ini bertepatan dengan kajian saintifik telah dibuat berkenaan perubahan daripada sudut fizikal, hormon dan psikologi ketika putus haid di Pantai Timur Semenanjung Malaysia yang berkait rapat dengan disfungsi seksual yang sering berlaku terhadap wanita yang telah menopaus di Malaysia (Malini Mat Napes et al. 2013). Malah dalam kajian menentukan kelaziman gejala prahaid (PMS) dalam populasi hidup bebas wanita Amerika Syarikat (Jadual 2). Kelaziman gejala yang lebih besar daripada $30 \%$ termasuklah berat badan, sakit kepala, gangguan kulit, kejang, kebimbangan, sakit belakang, keletihan, sakit payudara, cepat marah, perubahan emosi, kemurungan atau ketegangan. Hanya 2-8\% wanita didapati mempunyai gejala yang lebih teruk seperti lumpuh. Manakala kekejangan, sakit belakang, keletihan dan ketegangan adalah gejala yang paling lazim (Nancy 1982).

Tambahan pula, persetubuhan antara suami isteri adalah dilarang sama sekali oleh Islam ketika pendarahan haid. Ini kerana tiada persenyawaan akan berlaku jika persetubuhan dilakukan (Richard \& Kristin 2014) sedangkan maqasid syariah daripada persetubuhan ialah melahirkan zuriat.

\section{KESIMPULAN}

Fasa dan ciri saintifik yang sering digunakan dalam kitaran haid adalah bertepatan dengan ajaran Islam. Malah, pendarahan haid dibuktikan secara saintifik tentang kelebihannya dalam bertindak sebagai anti bakteria, mengandungi sel stem dan membantu dalam kesuburan wanita. Hal ini selari dengan maqasid syariah dalam memelihara jiwa dan keturunan serta membuktikan Islam memberi hikmah dengan memberi rehat kepada wanita berhaid yang kebiasaannya mengalami gejala kelaziman prahaid (PMS).

\section{PENGHARGAAN}

Pengarang mengucapkan terima kasih kepada kod projek penyelidikan FRGS/2/2013/SSI03/UKM/03/2, AP-2014020 dan DPP-2015-FPI yang telah memberi sokongan sehingga terhasilnya penulisan ini. 
JADUAL 2. Kelaziman gejala prahaid (PMS) dalam populasi wanita Amerika Syarikat

\begin{tabular}{|c|c|c|c|c|c|c|c|}
\hline & \multirow{2}{*}{ Gejala } & \multicolumn{2}{|c|}{ Haid } & \multicolumn{2}{|c|}{ Prahaid } & \multicolumn{2}{|c|}{ Selebihnya } \\
\hline & & $\mathrm{M} / \mathrm{M}^{\mathrm{b}}$ & $\mathrm{S} / \mathrm{D}^{\mathrm{c}}$ & $\mathrm{M} / \mathrm{M}$ & $\mathrm{S} / \mathrm{D}$ & $\mathrm{M} / \mathrm{M}$ & $\mathrm{S} / \mathrm{D}$ \\
\hline $1^{\mathrm{a}}$ & Berat naik & 30.7 & 2.2 & 40.2 & 5.6 & 14.0 & 2.8 \\
\hline 3 & Menangis & 15.6 & 2.8 & 19.6 & 4.5 & 4.5 & 1.7 \\
\hline 4 & Kurang prestasi di tempat kerja/sekolah & 14.5 & 3.9 & 11.7 & 3.4 & 7.8 & 1.7 \\
\hline 8 & Tidur & 22.9 & 3.4 & 17.3 & 1.1 & 7.8 & 1.7 \\
\hline 9 & Sakit kepala & 27.4 & 7.3 & 27.4 & 7.3 & 11.7 & 4.5 \\
\hline 10 & Penyakit kulit & 30.2 & 3.4 & 32.4 & 6.7 & 17.3 & 1.7 \\
\hline 16 & Kekejangan & 36.3 & 16.8 & 24.6 & 6.1 & 10.1 & 3.4 \\
\hline 21 & Kerisauan & 20.2 & 3.9 & 27.0 & 3.4 & 11.8 & 2.2 \\
\hline 22 & Sakit belakang & 25.1 & 6.1 & 16.8 & 5.0 & 10.1 & 1.7 \\
\hline 25 & Keletihan & 40.2 & 7.3 & 28.5 & 3.9 & 19.6 & 1.1 \\
\hline 30 & Sakit payudara & 25.1 & 4.7 & 27.9 & 7.6 & 8.1 & 1.7 \\
\hline 34 & Bengkak & 34.3 & 4.7 & 39.5 & 5.2 & 8.9 & 2.2 \\
\hline 36 & Cepat marah & 37.8 & 11.0 & 44.2 & 12.2 & 14.0 & 3.5 \\
\hline 38 & Perubahan emosi & 43.0 & 3.5 & 46.5 & 4.7 & 22.1 & 1.7 \\
\hline 40 & Depresi & 29.7 & 5.2 & 29.7 & 7.0 & 16.9 & 1.7 \\
\hline 45 & tertekan & 37.8 & 5.8 & 34.3 & 7.6 & 20.3 & 3.5 \\
\hline
\end{tabular}

${ }^{a}$ Bilangan selaras dengan bilangan item pada $\mathrm{MDQ}^{5}$

${ }^{\mathrm{b}}$ Tidak begitu kuat, sederhana

${ }^{\mathrm{c}}$ Kuat, tidak upaya.

Sumber: Nancy et al. 1982

\section{RUJUKAN}

Al-Quran

Abu Daud, Sulayman ibn al-Ash'ath. T.th. Sunan Abi Daud. Suntingan Muhammad Muhyi al-Din 'Abd al-Hamid. 4 jil. Beirut: Maktabah al-'Asriyyah.

Baird, D.D., Weinberg, C.R., Zhou, H., Kamel, F., McConnaughey, D.R. \& Kesner, J.S. 1999. Preimplantation urinary hormone profiles and the probability of conception in healthy women. Fertil Steril 71: 40-49.

Beckman, C.R.B.,Ling, F.W.,Hebert, W.N.P.,Laube, D.W., Smith, R.P. \& Barzansky, B.M. 1998. Obstetrics and Gynecology. Baltimore: Williams and Wilkins.

Chan, R.W., Schwab, K.E. \& Gargett, C.E. 2004. Clonogenicity of human endometrial epithelial and stromal cells. Biol. Reprod. 70: $1738-1750$.

Cho, N.H., Park, Y.K., Kim, Y.T., Yang, H. \& Kim, S.K. 2004. Lifetime expression of stem cell markers in the uterine endometrium. Fertil. Steril. 81: 403-407.

Cui, C.H., Uyama, T., Miyado, K., Terai, M., Kyo, S., Kiyono, T. \& Umezawa, A. 2007. Menstrual blood-derived cells confer human dystrophin expression in the murine model of Duchenne muscular dystrophy via cellfusion and myogenic transdifferentiation. Mol. Biol. Cell 18: 1586-1594.

De Coppi, P., Barstsch, G., Siddiqui, M.M., Xu, T., Santos, C.C., Perin, L., Mostoslavsky, G., Serre, A.C., Snyder, E.Y., Yoo, J.J., Furth, M.E., Soker, S. \& Atala, A. 2007. Isolation of amniotic stem cell lines with potential for therapy. Nat. Biotech. 25: 100-106.

Dunson, D.B., Baird, D.D., Wilcox, A.J. \& Weinberg, C.R. 1999. Day-specific probabilities of clinical pregnancy based on two studies with imperfect measures of ovulation. Hum. Reprod. 14: 1835-1839.

Egbert, R.V. \& Peter, L.P. 2002. The variability of female reproductive ageing. Human Reproduction Update 8(2): 141-154.

Ferenczy, A. 2003. Patophysiology of endometrial bleeding. Maturitas 45: 1-14.
GFDL. https://ms.wikipedia.org/w/index. php? curid=35650. Diakses pada 16 Mei 2016.

Hechtman, L. 2014. Clinical Naturopathic Medicine. Australia: Elsevier Australia.

Medical dictionary. 2013. http://www.online-medical-dictionary. org/definitions-m/menstruation.html. Diakses pada 4 April 2016.

Ibn al-Najjar, Muhammad bin Ahmad al-Futuhi. 1993. Sharh alKawkab al-Munir. Suntingan Muhammad al-Zuhayli \& Nazih Hammad. 4 jil. Riyadh: Maktabat al-'Abikan.

Karelin, A.A., Blishchenko, E.Y. \& Ivanov, V.T. 1998. A novel system of peptidergic regulation. FEBS Lett. 428(1-2): 7-12.

Kearns, M. \& Lala, P.K. 1982. Bone marrow origin of decidual cell precursors in the pseudopregnant mouse uterus. J. Exp. Med. 155: 1537-1554.

King, A.E., Critchley, H.O. \& Kelly, R.W. 2003. Innate immune defences in the human endometrium. Reprod.Biol. Endocrinol. 1: $116-123$.

Lamprecht, V.M. \& Grummer-Strawn, L. 1996. Development of new formulas to identify the fertile time of the menstrual cycle. Contraception 54: 339-343.

Levy, O., Ooi, C.E., Weiss, J., Lehrer, R.I. \& Elsbach, P. 1994. Individual and synergistic effects of rabbit granulocyte proteins on Escherichia coli. J. Clin. Invest. 94: 672-682.

Liepke, C., Baxmann, S., Heine, C., Breithaupt, N., Standker, L. \& Forssmann, W.G. 2003. Human hemoglobin-derived peptides exhibit antimicrobial activity: A class of host defense peptides. J.Chromatogr. B.Analyt. Technol.Biomed.Life Sci. 791: 345-356.

Ludwig, T.E., Levenstein, M.E., Jones, J.M., Berggren, W.T., Mitchen, E.R., Frane, J.L., Crandall, L.J., Daigh, C.A., Conard, K.R., Piekarczyk, M.S.,Llanas, R.A. \& Thomson J.A. 2006. Derivation of human embryonic stem cells in defined conditions. Nat. Biotechnol. 24: 185-187.

Mak, P., Szewczyk, A., Mickowska, B., Kici'nska,A . \& Dubin,A. 2001. Effect of antimicrobial apomyoglobin 56-131 peptide on liposomes and planar lipid bilayer membrane. Int. $J$. Antimicrob. Agents 17: 137-142. 
Mak, P., W’ojcik, K., Silberring, J. \& Dubin,A. 2000. Antimicrobal peptides from heme-containing proteins: Hemocidins. Antonie van Leeuwenhoek 77: 197-200.

Manges, A.R., Johnson, J.R., Foxman, B., O’Bryan, T.T., Fullerton, K.E. \& Riley, L.W. 2001. Widespread distribution of urinary tract infections caused by a multidrug-resistant Escherichia coli clonal group. N. Engl. J. Med. 345: 1007-1013.

Mat Napes, M., Sidi, H., Ahmad, S., Mohd Naim, N., Midin, M., Mohd Kassim, M.Z., Dahalan, R., Tan, L.K. \& Ng, C.G. 2013. Prevalence and associated factors of sexual dysfunction in Malaysian menopausal women. Sains Malaysiana 42(7): 1011-1017.

Muhammad Adib Samsudin, Mohammad Zaini Yahaya, Mohd Izhar Ariff Mohd Kashim, Hayatullah Lalulddin, Ahmad Munawar Ismail, Rozida Mohd Khalid, Irwan Mohd Sobri \& Syed Azhar Syed Sulaiman. 2015. Establishment of Shari'ah supervisory committee in Hospital: An analysis from perspective of public interest. Asian Social Science 11(4): 43-47.

Nancy, F.W., Ada, M. \& Gretchen, K.D. 1982. Prevalence of perimenstrual symptoms. Am. J. Public Health. 72(11): 1257-1264.

Nandoe, T.R.D., Hurtado, A., Levi, A.D., Grotenhuis, J.A. \& Oudega, M. 2006. Bone marrow stromal cells for repair of the spinal cord: Towards clinical application. Cell Transplant 15: 563-577.

al-Nawawi, Muhyi al-Din Yahya ibn Sharaf.T.th.al-Majmu'Sharh al-Muhadhdhab. 23 jil. Jedah: Maktabat al-Irshad.

al-Nawawi, Muhyi al-Din Yahya ibn Sharaf. 1992. Rawdat alTalibin. 6 jil. Beirut: Dar al-Kutub al-'Ilmiyyah.

Parish, C.A., Jiang, H., Tokiwa, Y., Berova, N., Nakanishi, K., McCabe, D., Zuckerman, W., Xia, M.M. \& Gabay, J.E. 2001. Broad-spectrum antimicrobial activity of hemoglobin. Bioorg. Med. Chem. 9(2): 377-382.

Patel, A.N., Geffner, L., Vina, R.F., Saslavsky, J., Urschel Jr., H.C., Kormos, R. \& Benetti, F. 2005. Surgical treatment for congestive heart failure with autologous adult stem cell transplantation: A prospective randomized study. J. Thorac. Cardiovasc. Surg. 130: 1631-1638.

Petrov, R.V., Mikhailova, A.A.\& Fonina,L.A. 1997. Bone marrow immunoregulatory peptides (myelopeptides): Isolation, structure, and functional activity. Biopolymers 43: 139-146.

Preethi, S. \& Jayanthi, A. 2012. Antimicrobial properties of haemoglobin. Immunopharmacology and immunotoxicology 34(6): 896-900.

Quayle, A.J. 2002. The innate and early immune response to pathogen challenge in the female genital tract and the pivotal role of epithelial cells. J. Reprod. Immunol. 57: 61-79.

Richard, E.J. \& Kristin, H.L. 2014. Human Reproductive Biology. 4th ed. Oxford: Elsevier's Science \& Technology Right Department. hlm. 54.

Russell, M.W. \& Mestecky, J. 2002. Humoral immune responses to microbial infections in the genital tract. Microbes Infect. 4: 667-677

Saunders, N.J. \& Cohen, J. 1995. A study of the interaction between recombinant bactericidal permeability increasing protein (rBPI23) and gentamycin. Int. J. Antimic. Agents 5: 259-263.

Schwab, K.E. \& Gargett, C.E. 2007. Co-expression of two peri vascular cell markers isolates mesenchymal stem-like cells from human endometrium. Hum. Reprod. 22: 2903-2911.

Shai, Y. 1999. Mechanism of the binding, insertion and destabilization of phospholipid bilayer membranes by alpha- helical antimicrobial and cell non-selective membrane-lytic peptides. Biochim. Biophys. Acta. 1462: 55-70.

al-Sharbini, Shams al-Din Muhammad bin Muhammad al Khatib. 1994. Mughi al-Muhtaj Ila Ma'rifat Ma'ani Alfaz al-Minhaj. 6 jil. Beirut: Dar al-Kutub al-'Ilmiyyah.

al-Shatibiyy, Ibrahim bin Musa al Lakhmiyy. T.th. al Muwafaqat fi Usul al-Shari'ah.sunt. Abdullah Darraz. 2 jil. Beirut: Dar al Kutub al-'Ilmiyyah.

Taylor, H.S. 2004. Endometrial cells derived from donor stem cells in bone marrow transplant recipients. JAMA 292: 81-85.

Thomson, J.A., Itskovitz-Eldor, J., Shapiro, S.S., Waknitz, M.A., Swiergiel, J.J., Marshall, V.S. \& Jones, J.M. 1998. Embryonic stem cell lines derived from human blastocysts. Science 282 1145-1147.

Toma, C., Pittenger, M.F., Cahill, K.S., Byrne, B.J. \& Kessler, P.D. 2002. Human mesenchymal stem cells differentiate to a cardiomyocyte phenotype in the adult murine heart. Circulation 105: 93-98.

Treloar, A.E., Boynton, R.E., Behn, B.G. \& Brown, B.W. 1967. Variation of the human menstrual cycle through reproductive life. Int. J. Fertil. 12: 77-126.

Vilquin, J.T. \& Rosset, P. 2006 Mesenchymal stem cells in bone and cartilage repair: Current status. Regen.Med. 1: 589-604.

Wilcox,A.J., Weinberg, C.R.\& Baird,D.D. 1998. Post-ovulatory ageing of the human oocyte and embryo failure. Hum.Reprod. 13: 394-397.

Wilcox, A.J., Weinberg, C.R. \& Baird, D.D. 1995. Timing of sexual intercourse in relation to ovulation: Effects on the probability of conception, survival of the pregnancy and sex of the baby. N. Engl.J.Med.333: 517-521.

Zainal Ariffin, S.H., Zainal Abidin, I.Z., Senafi, S., Mahadi, N.M., Abdul Wahab, R.M.\& Zainal Ariffin,Z. 2005. Sel stem dalam perkembangan darah. Sains Malaysiana 34(2): 1-7.

Zurita, M. \& Vaquero, J. 2004. Functional recovery in chronic paraplegia after bone marrow stromal cells transplantation. Neuroreport 15: 1105-1108.

Nur Asmadayana Hasim

Institut Islam Hadhari

Universiti Kebangsaan Malaysia

43600 Bangi, Selangor Darul Ehsan

Malaysia

Mohd Izhar Ariff Mohd Kashim, Mohammad Zaini Yahaya \&

Muhammad Adib Samsudin*

Jabatan Syariah, Fakulti Pengajian Islam

Universiti Kebangsaan Malaysia

43600 Bangi, Selangor Darul Ehsan

Malaysia

Rizafizah Othaman \& Rozida Khalid

Pusat Pengajian Sains Kimia dan Teknologi Makanan

Fakulti Sains dan Teknologi

Universiti Kebangsaan Malaysia

43600 Bangi, Selangor Darul Ehsan

Malaysia

*Pengarang untuk surat-menyurat; email: adib@ukm.edu.my

Diserahkan: 17 Jun 2016

Diterima: 15 Ogos 2016 